\author{
메니에르병의 진단 \\ 인하대학교 의과대학 이비인후- 두경부외과학교실 \\ 김 규 성
}

\title{
Diagnosis of Meniere's Disease
}

Kyu Sung Kim, MD

Department of Otorhinolaryngology-Head \& Neck Surgery, College of Medicine, Inha University, Incheon, Korea

\section{서 론}

메니에르병은 1) 발작성 어지럼, 2) 난청, 3) 이명, 4) 이충만감을 특징적인 증상으로 하는 질환이며, 병태생리 는 '원인불명의 내림프수종(idiopathic endolymphatic hydrops)' 정의되어 있다. ${ }^{1)}$ 이처럼 어지럼을 유발하는 다른 질환보다 비교적 명확한 정의를 가지고 있는 반면, 내림프수종의 병인과 병태생리가 명확치 않고, 사망 후 측두골 병리소견 외 임상적으로 내림프수종을 명확히 진 단할 방법이 아직까지는 없다. 따라서 메니에르병의 진 단은 증상에 의존할 수 밖에 없다.

우리가 어떤 질병에 대하여 명확히 알기 위해서는, 진 단기준을 명확히 하고, 그 질병을 가진 동일한 집단에 대하여 치료하고 관찰하는 것이 기본이다. 예를 들어 어 지럼과 난청을 가진 다양한 질환을 메니에르병으로 간 주하고 동일한 진단법과 치료법을 동원한다면, 그 결과 의 변동성을 피할 수는 없을 것이며, 학문적 발전을 이 룰 수 없을 것이다. 내이질환 진단의 어려움과 메니에 르병에 대한 지식이 축적되어 온 역사를 보면, 이러한 문제를 해결하기 위한 의학자들의 노력이 깃들어 있음 을 알 수 있다.

교신저자 : 김규성, 400- 711 인천광역시 중구 신흥동 3가 7- 206 인하대학교 의과대학 이비인후 두경부외과학교실 전화 :(032) 890- 3620. 전송 :(032) 890- 2430 E- mail : stedman@inha.ac.kr
현재 메니에르병의 진단은 1995년 미국이비인후- 두 경부외과학회(AAO- HNSF)에서 제정한 진단기준을 전 세계적으로 널리 이용하고 있다. ${ }^{1)}$ 따라서 본문에서는 이 진단기준에 대하여 설명하고, 증상과 보조적 검사방법에 대하여 소개하고자 한다.

\section{진단기준의 발전 \\ (미국 이비인후-두경부외과학회AAO-HSNF)}

1972년“ 미국 안이비인후과학회 산하 청력평형소위 원회' 에서 정의 및 진단기준을 정하였고, 이 후' 미국 이비인후- 두경부외과학회(AAO- HNS) 산하 청력평형 위원회' 에서 1985년, 1995년에 걸쳐 두 차례 개정하였 다. 현재 가장 널리 사용되고 있는 이 진단기준에 대하 여 소개한다.

\section{2년}

이전까지 어지럼을 일으키는 모든 질환에 메니에르의 이름이 들어간 진단명을 쓰고, 그 명칭도 통일되어 있지 않던 역사적 배경을 가지고 단일한 진단기준의 필요성 에 의하여 만들어졌다. 발작적인 어지럼과 청력소실 및 이명을 특징으로 하며 병리학적으로는 내림프수종과 연 관된 막미로의 질환으로 정의하였고 질병명에 있어‘ 메 니에르병 Meniere's disease' 이외 다른 유사명칭은 사용하지 않기로 결정하였다. 또한 전정증상(어지럼) 과 청각증상(난청) 중 한가지의 증상만 보이는 비전형을 각 
각 와우 메니에르병과 전정 메니에르병이라는 아형(subtype) 명칭을 사용토록 하였으며, 치료효과의 보고 기 준을 만들었다. 그러나 이 후 역학적, 병리학적 연구를 통하여 이러한 비전형이 실제 전형적 메니에르병과 다른 질환일 가능성이 점차 제시되면서 1985년 더 엄격하게 진단기준을 개정하게 된다.

\section{5년 ${ }^{3)}$}

객관성(objectivity) 과 명확성(clarification) 을 목표로 개정되었다. 메니에르병을 전정 및 청각증상을 모두 가 지고 있는 경우로 한정하여 이전에 사용하던 와우 및 전 정 메니에르병이라는 용어를 없애 메니에르병의 범위를 보다 명확히 하였다. 또한 감별진단을 보다 강화하여 다 른 원인이 배제되는' 특발성(idiopathic)' 의 경우로 한 정하였으며, 치료효과의 보고기준을 어지럼 발작의 횟수, 청력, 및 장애정도 등으로 정량화, 세분화 하였다. 그러 나 실제로 원인을 알 수 없는 어지럼 및 난청질환 중 이 러한 전형적인 증상을 보이지 않는 임상례도 많고, 또 병의 발생 초기에 한 가지 증상만을 보이는 환자군에 대한 관리 및 추적에 있어 이러한 경직된 진단기준을 실 제적으로 적용하는데 있어서 어려움이 있어 1995년 다 시 개정하게 된다.

\section{5년 ${ }^{1)}$}

단순화( simplification) 하면서 포용성(flexibility) 를 목 표로 개정되었다. 기록과 분석을 구별하여 기록하므로써 마치 컴퓨터의 소프트웨어가 업그래이드 후에도 기존의 자료를 이용할 수 있는 것과 같의 개념으로 척도(scale) 체계가 도입되었다. 즉, 증상에 따라 certain, definite, possible, probable' 의 네 단계로 나누어(T able 1) 진 단기준을 모두 충족시키지 못하더라도 치료 및 추적관찰 에 있어 중요한 비전형의 환자군, 예를 들어 어지럼 혹 은 난청만을 증상으로 가지고 있는 경우를 포함하기로 하였다. 단, 연구보고에는 이 중' certain' 과 definite' 군만 적용키로 하였다.

또한 메니에르병의 병인을، 내림프수종에 의하여 발생 되는 원인불명 증후군(idiopathic syndrome)' 으로 확정 하여 정의하였다. 향후 원인- 내림프수종 증상' 의 관계, 즉 병인과 병태생리가 보다 명확해짐에 따라 개정될 여
Tabel 1. Diagnosis of Meniere's disease

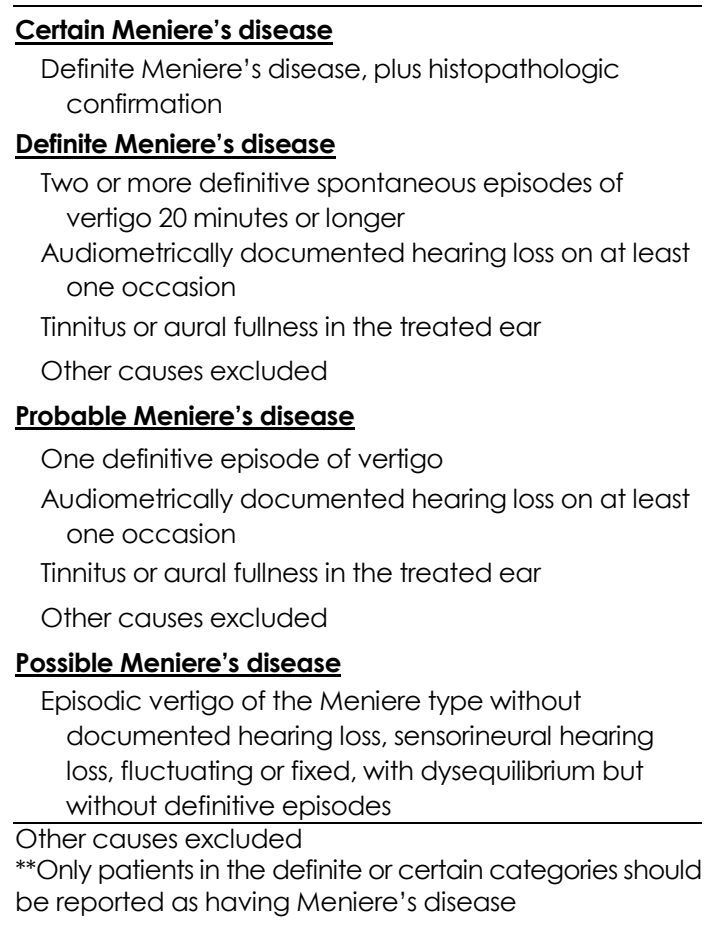

**Only patients in the definite or certain categories should be reported as having Meniere's disease

지가 있겠으나 현재 가장 널리 쓰이고 있는 이 1995년의 AAO- HNSF의 진단기준에 대하여 자세히 알아야 한다.

\section{미국 이비인후-두경부외과학회(AAO-HNS)의 진단기준(1995년)}

1995년도에 세 번째로 개정된 미국 이비인후- 두경부 외과학회 진단기준은 이전 기준의 문제점과 그 기간의 새로운 연구결과를 근거로 하여 개정되었으므로 새롭게 획기적인 연구 성과가 없는 한 현재까지 연구성과가 집 약된 기준이며, 메니에르병에 대한 학술연구를 발표하기 위한 기준이다. 따라서 그 내용을 정확히 이해하는 것이 필요하다.

여기서 메니에르병을' idiopathic syndrome of endolymphatic hydrops' 로, 병태생리학적 상태는' endolymphatic hy drops' 라고 정의하였다.

\section{어지럼}

메니에르병의 전형적 어지럼 발작은 최소 20 분 이상 
( 통상 수시간) 지속되는 자발성 회전성 어지럼' 이다. 발 작 후 수 일 정도는 불균형감을 느낄 수 있으며 구역, 구토의 자율신경계 증상을 동반한다. 일반적으로 어지럼 은 와우증상을 수반하지만 초기에 동반된 증상없이 시 작되는 경우도 있다. 의식소실은 없으며, 발작 중 수평 또는 수평회시성 안진이 동반한다. 이것을' 메니에르병 양상(Meniere ty pe) 의 발작성 어지럼' 이라고 한다.

\section{난 청}

메니에르병의 임상양상은 전정증상보다 와우증상에서 보다 다양하며, 특히 메니에르병의 진단, 좌우구별 및 감별진단에 와우증상이 단서가 되므로 중요하다. 그러 나 청력저하의 주관적 증상은 환자가 동측 귀에 이명이 나 이충만감을 느낄 때 실제 청력검사 상 난청이 없어 도 느낄 수 있으므로 반드시 청력검사를 통하여 객관적 으로 규명되어야 한다. 청력검사는 기본적으로 $0.5,1,2$, $3 \mathrm{kHz}$ 의 네 가지 주파수의 순음을 이용하며, 이때 나타 난 난청은 다음 중 하나 이상을 따라야 한다. $0.25,0.5$, $1 \mathrm{kHz}$ 의 청력역치 평균이 $1,2,3 \mathrm{kHz}$ 평균보다 $15 \mathrm{~dB}$ 이상 높거나, 일측성의 경우 의심되는 쪽의 $0.5,1,2,3$ $\mathrm{kHz}$ 의 청력역치 평균이 반대쪽보다 $20 \mathrm{~dB}$ 높거나, 양 측성의 경우 $25 \mathrm{~dB}$ 이상. 또한 청력역치 평균이 $10 \mathrm{~dB}$ 이상, 어음변별력이 $15 \%$ 이상 변동되었을 때 임상적으 로 의미가 있는 것으로 간주하였고, 예를 들어 청력역치 평균은 악화되고 어음변별력은 호전되었을 때와 같이 두 가지 결과가 반대로 변할 때는 청력역치 평균을 기준으 로 호전 및 악화를 결정한다.

\section{이명 및 이충만감}

반면 메니에르병의 특징이며, 병의 초기에 현저한 난 청의 변동성에 대해서는 항상 있는 것이 아니므로 진단 기준으로 필요성은 부인하였고, 이명과 이충만감에 대해 서도 별도의 기준을 부여하지 않았다.

\section{기타 진단적 고려점}

내림프수종을 임상적으로 진단할 수 있는 확실한 검사 법이 없는 상태에서 임상증상만을 진단기준으로 삼는 것 은, 내이질환의 다양성을 고려하였을 때 많은 문제점을 내포할 가능성이 높다. 따라서 검사법과 감별진단에 대
하여 보다 엄격한 몇 가지 고려점, 즉' 이런 경우 메니 에르병이 아니다' 라는 것에 대하여 기술하고 있다.

반복성 어지럼이 있더라도 청력저하가 없는 경우, 청 력저하가 동반된 어지럼이 있어도 한번만 발생한 경우 와 같이 진단기준 상(T able 1) ' probable', possible' 에 해당하거나, 예전 진단기준 상 전정 또는 와우 메니 에르병으로 분류되었던 증례들은 메니에르병이 아닐 수 있다.(물론 현재 진단기준 상 definite'에 해당되지 않 지만, 나중이라도 전자의 경우 청력저하가 동반되거나, 후자의 경우 동일한 어지럼 발작이 재발한다면 메니에 르병이라 할 수 있다.)

보고에 따라 발생빈도의 차이가 커서(3 75\%) 진단 기준에 논란의 여지가 많은 양측성 메니에르병에 대하 여 좀 더 엄격한 감별을 권유하고 있다. 양측 청력이 수 주 내지 수개월에 걸쳐 순차적으로 저하되어도 면역억 제제에 반응을 보인다면 원인불명성이 아니고 자가면역 질환, 알레르기, 또는 내이매독과 같은 면역성 혈관염에 기인할 가능성이 높으므로 이런 경우 메니에르병이라고 진단을 내리지 말아야 하며, 양측의 청력역치 평균이 $70 \mathrm{~dB}$ 이상, 어음변별력이 $50 \%$ 이하인 경우 메니에르 병이라는 진단을 의심해 볼 필요가 있다고 하였다.

과거 메니에르병의 병력이 없지만 사후 측두골 병리소 견에서 내림프수종이 발견되는 경우가 있으며, 이러한 경 우 메니에르병이라고 진단할 수 있을 것인가의 문제가 제기되어 왔다. 1983년 Schuknecht \& Gulya ${ }^{4)}$ 는 이를 '증상형 내림프수종' 과 구별하여' 무증상형 내림프수종' 이라고 칭하였고, 메니에르병의 병태생리 메커니즘을 내 림프액의 축적이 증상과 연관된 막미로의 파열과, 이 결 과로 일어나는 내이감각세포의 비가역적 변화가 영구적 인 청력 및 전정기능 감소를 일으키는 것으로 설명하였 다. 증상형 내림프수종의 조건으로 1) 내림프수종은 반 드시 막미로의 파열을 일으킬 수 있도록 진행적(progressive)이어야 하고, 2) 내이기관은 이러한 진행적 내 림프수종에 반응할 수 있도록 기능이 남아 있어야 한다 고 하였다. 반면 무증상형 내림프수종의 경우 1) 내림프 수종은 진행적이지 않거나, 2) 반응을 일으킬만한 내이 기능이 남아있지 않거나, 3) 내,외림프액 사이에 영구적 누공을 형성하고 있어 막미로의 파열에 반응하지 않기 때문일 것이라고 설명하였다. 이 후 이중맹검 측두골 병 
리조직검사를 시행하여‘ 메니에르병( 즉, 증상이 있는) 은 $100 \%$ 에서 내림프수종을 가지고 있다'라고 보고의 뒷받 침을 받게 되었고, 이와 같은 역사적 배경을 근거로 본 진단기준 ${ }^{1)}$ 에서는 다음과 같이 정의하고 있다. '병리소견 에서 보이는 내림프수종은 메니에르병이 아닌 외상, 감 염에서도 발생될 수 있으며, 이처럼 특정 원인이 있건 특발성이건 간에 비진행성이거나 무증상, 즉 어지럼이 발생되지 않았다면 메니에르병이라는 진단을 내릴 수 없다.' 물론 증상이 없는데 임상적 진단을 내리는 경우 는 없다. 그러나 현재까지 환자의 사후 측두골의 병리소 견에서 내림프수종을 발견하는 것이 메니에르병의 가장 확실한 확진법일수 밖에 없는 상황에서 측두골병리에 내림프수종이 있다고 무조건 메니에르병이라는 진단을 사후에 내릴 수는 없다는 내용의 이론적 배경이 되는 것이다. 진단척도에서도' certain' 이 되기 위해서는 병 리소견에 추가하여' definite' 에 해당되는 증상이 있어 야 되는 것으로 정의하고 있다.

내이매독, 코간증후군 등 청력저하와 함께 어지럼을 유발하는 질환에 대한 감별진단의 중요성과, 메니에르병 이 원인불명의 질환이라는 점을 강조하고 있다.

이와 같은 증상을 기준으로 다음과 같이 메니에르병 의 네 단계 진단척도를 도입하였다(T able 1).

참고로 일본의 경우 일본어지럼평형의학회 산하 어지 럼 진단기준화 위원회' 에서 제정하여1995년에 일본평 형의학회지에 발표한 별도의 진단기준을 사용하고 있다 ( $\mathrm{T}$ abel 2).

\section{증 상}

\section{전정증상}

메니에르병의 전형적 어지럼은 자발성 회전성 어지 럼' 이다. 일반적으로 어지럼은 와우증상을 수반하지만 초기에 동반된 증상 없이 시작되는 경우도 있다. 어지럼 의 지속 기간 및 강도는 일정한 규칙성은 없으나 통상 자발적, 발작적으로 생긴 어지럼의 지속시간은 수십분에 서 수시간에 이른다. 회전성 어지럼 발작 사이에 흔들리 는 느낌, 떠있는 느낌 등 비회전성 어지럼이나 체위성 어지럼을 반복하는 경우도 있다. 장기 관찰에서 어지럼 의 강도 및 빈도는 메니에르병의 후기가 되면 경감된다.
Table 2. Diagnosis of Meniere's disease ( Japan Society for Equilibrium Research, 1987)

\section{1. 질환개념}

원인불명의 내림프수종

2. 병력으로부터의 진단

1) 반복되는 발작성의 회전성 어지럼

2) 어지럼 발작에 동반되어 변동하는 와우증상 (이명, 난청)

3) 제 8 뇌신경 이외의 신경학적 증상은 없음

4) 원인 불명

1) , 2), 3) , 4)을 모두 만족할 때 메니에르병을 의심

3. 검사로부터의 진단

1) 청력검사로 메니에르병에 특징적인 난청을 확인

2) 평형기능 검사에서 내이장애의 소견을 확인

3) 신경학적 검사에서 어지럼에 연관된 제 8 뇌신경 이외 의 장해는 없음

4) 이비인후과적, 내과적, 임상병리학적 검사 등에서 내이 장애의 명확한 원인이 불명

4. 종합 판정

1) 메니에르병을 확정하는 경우

: 병력에서 메니에르병을 의심하고 검사에서 1- 4)를 만족할 때

2) 메니에르병을 대략 확정하는 경우

: 병력은 만족하지만 검사에서는 가끔만 만족하거나 항 상 음성소견을 보일 때

\section{와우증상}

메니에르병의 임상양상은 전정증상보다 와우증상에서 보다 다양하며, 특히 메니에르병의 진단, 좌우구별 및 감 별진단에 와우증상이 단서가 되므로 중요하다. 메니에르 병, 난청의 가장 큰 특징은 변동하는 감음신경성 난청이 다. 그 전형적인 청력변동은 어지럼 발작 전, 동시 또는 후에 볼 수 있으나 어지럼과 관계없이 변동하는 경우도 있다. 청력은 고음역보다 중저음 영역이 크게 변동한다. 청력형은 저음 장애형이나 산형(peak형)이 많다. 단지 청력 변동이 있기 때문에 병기 중에 중저음 난청이 개선 되어 고음장애형으로 보이게 되는 경우도 있다. 스웨덴 의 역학조사에서 20 년 이상 경과하면 $85 \%$ 의 증례가 50 $\mathrm{dB}$ 전후의 난청에 도달하며, 청력형은 초기에는 변동성 으로 저음장애형이 많지만 후기에 이르면 변동성이 없어 지며 수평형을 보이는 경우가 많다. ${ }^{5)}$ 난청은 질환이 진 행되어도 전농( 全壟) 으로 진행되는 경우는 드물기 때문 에 이럴 경우 다른 질환을 감별할 필요가 있다. ${ }^{1)}$

이명을 동반하는 것도 메니에르병 난청의 특징으로 난 청 발생측과 동측이며, 발작기에는 저음성, 중간기에는 
고음성의 이명이 많고, 강도는 대부분 변동하는 난청의 정도와 연관되므로 메니에르병을' 3대 증상' 으로 표현 할 경우 이명은 변동성 난청과 함께 청력증상에 포함시 킨다. 이충만감은 특정한 원인에 의하여 내림프수종을 형성하는 질병 이외의 다른 이과질환에서는 드물기 때 문에 메니에르병의 중요한 특징이 될 수 있다. 이외에도 보충현상의 일종인 청각과민, 음이 갈라져 들리는 복청 등을 호소하기도 한다.

\section{그 외의 증상}

일반적인 어지럼 질환에서 볼 수 있듯이 발작시 통상 구역, 구토 등의 자율신경계 증상을 동반한다. 때로는 환 자가 명확한 어지럼을 자각하지 못한 상태로 이러한 위 장관 증상만을 느껴 소화기내과 만을 방문한 병력을 가 진 경우도 드물지 않다. 머리가 무겁고 어깨 결림, 목의 통증도 자주 볼 수 있는 동반증상이다.

\section{검 사}

메니에르병을 진단하는 검사방법이란 결국 그 병태생 리학적 상태인 내림프수종을 진단해 내는 방법을 의미한 다. 다양한 검사방법이 시도되고 있지만 증상 중 하나인 청력변동을 객관적으로 증명하기 위한 청력검사 외( 물론 이것이 확진방법이 될 수는 없다.) 안정된 소견을 보이 는, 즉 golden standard 검사법이 없어, 검사소견 상 양 성이 메니에르병의 확진이 아니며, 음성 또한 배제를 의 미하는 것은 아니라는 것을 염두에 두어야 한다. 이는 메 니에르병이 다양한 병인 및 병태생리를 보이는 다인성 질환이기 때문일 뿐 아니라, 원인불명의 질환이기 때문 이기도 할 것이다. 따라서 아래 소개하는 검사법은 첫째, 임상양상의 기초로 내린 진단의 보조적 정보를 제공하고, 둘째, 어지럼과 난청의 유사한 증상을 보이는 다른 질환 을 감별하는 목적으로 유용성을 갖는다고 할 수 있으며, 전정기능을 파괴하거나, 청력소실의 위험성이 큰 치료법 을 선택할 때 중요한 정보를 얻을 수 있다는 측면에서 중요하다.

\section{안진검사}

프렌첼 안경, 전기안진기 또는 비디오안진기를 이용하
여 발작기 자발안진을 관찰할 수 있다. 이 때 안진의 특 징은 1) 출현이 어지럼 발작 중 일과성으로 나타나고, 2) 수평회전성 안진을 보이며, 3) 통상 발작 초기 병변 측을 향하는 자극성(irritative) 안진, 후기에는 정상측을 향하는 마비성(paralytic) 안진, 발작이 소실된 후 다시 병변측을 향하는 회복성(recovery)안진을 보인다. 그 러나 안진의 방향은 발작기의 병태와 진찰시점에 따라 다양할 수 있으므로, 안진소견은 참조할 수 있으나, 진단 및 병변측 결정에 도움을 주는 것은 아니다.

\section{순음청력검사}

청력검사를 통하여 객관적으로 입증된 난청은 메니에 르병의 진단과 좌우측 구별에 가장 중요한 소견을 제공 한다. 감음신경성 난청 및 자각하지 못하는 경미한 청력 소실이나 저음장애를 확인할 수 있고 청력검사를 반복 하여 청력 변동 유무, 치료의 반응을 확인 할 수 있다. 시간차를 두고 양측으로 발생되는 경우 나중에 발생되 는 쪽의 증상은 어지럼이 상대적으로 약하여 청력검사 상의 청력저하가 진단에 더욱 중요한 단서가 된다. 초기 순음청력검사 소견은 저주파가 상대적으로 심한 감각신 경성난청을 보이지만, 병이 점차 진행되면 수평형이 약 $41 \sim 74 \%$ 의 빈도로 보고되고 있다. 연속적인 검사에서 청력이 변동성을 확인할 수도 있지만, 이러한 청력의 변 동이 진단의 필요조건은 아니다. 그러나 이러한 청력변 동은 주로 병의 초기, 활동기에 주로 관찰되고, 후기로 진행되면 $60 \mathrm{~dB}$ 전후의 청력 역치에서 고정되는 경향 을 보이며, 청력의 변동성도 감소된다. ${ }^{6)}$

기타 청력검사로 보충현상 검사 및 뇌간유발반응검사 등을 감별진단을 목적으로 시행할 수는 있지만 확진을 위한 유용성은 없다.

\section{전기와우도}

메니에르병의 확진소견은 아니지만, 현재까지 내림프 수종을 확인하기 위하여 시행되는 검사방법 중 가장 중 요한 비중을 차지한다. 검사방법은 활성전극의 부착부위 에 따라 고막을 뜷고 와우갑각에 부착하는 고실내유도 법과 외이도에 부착하는 고실외유도법이 있다. 자극음은 클릭음이나 단음(tone burst)가 이용된다. summating potential의 마이너스 성분(- SP)의 증가가 메니에르병 
김규성 : 메니에르병의 진단

을 가진 환자에서 고정적으로 측정되지만 - SP 증가의 단독소견은 개인차 및 전극부착 부위 등의 검사방법에 따라 변화가 크기 때문에 action potential(AP)에 대한 - SP의 상대값인 - SP/AP ratio'을 지표로 한다. 전극 부착방법 및 자극음에 따라 비율값이 다르므로 검사실 에 따라 반복검사를 통하여 통상 표준편차의 3 배에 해 당되는 값을 정상기준으로 삼는데, 고실내유도법의 경우 0.25 , 고실외유도법의 경우 0.45 이상이 되는 경우 통 상 비정상으로 판정하게 된다. ${ }^{7)}$ 보고에 따라 다소 차이 는 있으나 메니에르병의 $60 \%$ 이상에서 양성을 보이며, 기타 내이매독에서도 높은 양성율을 보이지만 아미노글 리코시드 등 이독성약물에 의한 유모세포 장애로 일어 나는 난청의 경우 음성을 보인다.

양성률이 높지 않아 보조적인 진단법의 한계가 있고, 병의 장기관찰에서 청력 악화 또는 개선에 의하여 - SP 의 증대 또는 감소가 관찰되지 않은 반면, 고음역 청력 과 상관관계를 보여 내림프압의 증가보다는 외유모세포 의 장애를 반영하고 있을 가능성이 있다는 점, 청신경종 양이나 외림프누공에서 양성이 나올 수 있다는 점 등이 제한점으로 지적되기도 한다. 한편 전기와우도가 주로 고 음역을 반영하고, 내림프수종을 검출하기 위한 글리세롤 검사의 청력변동이 주로 저음역에서 일어나기 때문에 두 방법의 병용을 통하여 진단율을 높일 수 있다.8)

\section{탈수검사}

내림프수종을 검출하는 탈수검사로서 퓨로세마이드(furosemide) 검사 및 글리세롤( gly cerol) 검사가 있다. 이 뇨제로 수종을 경감시킨 후 내이기능의 개선 여부를 평 가하고자 하는 검사이며, 전자는 전정기능을, 후자는 와 우기능을 지표로 이용한다.

퓨로세마이드 검사

성인에서 퓨로세마이드(라식스 $\left.{ }^{\circ}\right) 2 \mathrm{ml}(10 \mathrm{mg} / \mathrm{ml}$ ) 를 정맥주사 후 온도안진검사에서 안진의 최대완서상속도 및 회전자극에서 전정안반사 이득의 개선을 지표로 평 가한다. 메니에르병의 50 60\% 가 양성 소견을 보이며 청각을 지표로 하는 감별 검사가 이루어지지 않는 경우 에는 유용하다.

\section{글리세롤 검사}

글리세롤 $(1.2 \sim 1.5 \mathrm{~g} / \mathrm{kg})$ 의 경구복용 전후의 순음청력 역치의 변동을 지표로 한다. 기준은 조금씩 다르지만 통 상 글리세롤을 내복한 3 시간 후 순음청력검사 상 연속 한 두 주파수에서 $10 \mathrm{~dB}$ 이상, 어음판별수치에서 $10 \%$ 이상의 개선을 보이는 경우 양성으로 한다. 중저음을 중 심으로한 주파수역의 청력개선으로 나타나며 양성소견은 청력이 악화된 당시에 보다 출현하기 쉽지만 일반적으로 47 60\% 에서 양성 소견을 볼 수 있다. 글리세롤에 의 한 청력 개선은 리바운드(rebound) 현상이 있으므로 메 니에르병의 치료에는 적용하지 않는다. 경구 글리세롤은 복용 후 $30 \%$ 이상에서 두통이 발생되며, 마시기에 역겹 고, 장내 흡수율의 차이 등이 있을 수 있어 정맥주사를 이용하기도 한다.

탈수검사는 두개강 내 질환, 심부전, 신부전, 당뇨 또 는 치료목적의 염분섭취 제한환자 등에서 부작용이 발생 될 수 있으므로 주의하여야 한다.

\section{전정기능검사}

메니에르병이 내이에서 기원되므로 일측의 말초전정기 능 저하소견을 기대하지만 실제로 전정기능검사 소견은 약 $50 \%$ 에서 정상소견을 보여 진단에 도움이 되지 못한 다.9) 이는 어지럼 발작이 있더라도 실제 전정기능 저하 는 작고, 또 검사법의 한계, 즉 가쪽반고리관의 기능만 을 반영하기 때문일 수 있다. 전정기능검사는 경과관찰 을 위한 기초적 자료, 감별진단, 그리고 전정신경절제술, 미로절제술, 고실내 아미노글리코시드 주입법 등과 같이 전정기능을 파괴하는 치료법을 동원할 때 반대측 전정 기능을 확인하기 위한 경우에 유용하다고 할 수 있다.

\section{방사선학적 검사}

아직까지 메니에르병의 영상검사의 의의는 전정도수관 의 발육정도나 내이의 기형을 평가하고 전정 및 내이도 의 종양이나 후두개외종양을 감별하고, 수술 전 검사 정 도 이상의 정보를 제공하지는 못하고 있다. 그러나 최근 $\mathrm{MRI}$ 로 와우의 라이스너막을 촬영하여 측두골 병리소견 과 같은 내림프강의 팽대를 영상으로 확인하고자 연구가 진행 되고 있다. 사람의 측두골을 대상으로 4.7T (테슬 라), ${ }^{10)}$ 기니픽에서 7.01T 의 MRI로 성공적인 영상을 얻 
었다. ${ }^{11)}$ 현재 일반적으로 쓰이는 $1.5 \mathrm{~T}$ 의 MRI에서도 기 저판의 확인은 가능한 정도까지 발전되어 있으나, 향후 환자를 대상으로 내림프수종을 확진하기 위한 정밀한 영상을 얻기 위해서는 기기, 자기장, 조영제, 하드웨어의 개선, 시간, 공간분해능 등 촬영시퀀스의 개선, 호흡 및 신체 움직임의 영향배제 등과 같은 소프트웨어의 개선 이 함께 이루어져야 할 것으로 생각된다.

중심 단어 : 메니에르병. 내림프수종.

\section{REFERENCES}

1) Monsell EM. Committee on Hearing and Equilibrium guidelines for the diagnosis and evaluation of therapy in $\mathrm{Me}$ niere's disease. Otolaryngol Head Neck Surg 1995;113: 181-5.

2) Committee on Hearing and Equilibrium. Ménière's disease: criteria for diagnosis and evaluation of therapy for reporting. Trans Amer Acad Ophth Otolaryngol 1972;76:1462-4.

3) Pearson BW, Brackmann DE. Committee on Hearing and Equilibrium guidelines for reporting treatment result in Meniere's disease. Otolaryngol Head Neck Surg 1985;93:
579-82.

4) Schuknecht HF, Gulya AJ. Endolymphatic hydrops; An overview and classification. Ann Otol Rhinol Laryngol Suppl 1983;106:1-20.

5) Stahle J, Arenberg K, Stahle C. Incidence of Meniere's disease. Arch Otolaryngol 1978;104:99-104.

6) Costa SS, Sousa LCA, Piza MRT. Meniere's disease: overview, epidemiology, and natural history. Otolaryngol Clin N Am 2002;35:455-95.

7) Mori N, Asai H, Sakagami M. The role of summating potential in diagnosis and management of Meniere's disease. Acta Otolaryngol 1993;501 (suppl):51-3.

8) Mori N, Asai A, Suizu Y, Ohta K, Matsunaga T. Comparison between ECoch G and glycerol test in Meniere's disease. Scand Audiol 1985;14:209-13.

9) Paparella MM. Methods of diagnosis and treatment of Meniere's disease. Acta Otolaryngol Suppl 1991;485:108-19.

10) Koizuka I, Seo R, Sano M, Matsunaga T, Murakami M, Seo $\mathrm{Y}$, et al. High-resolution magnetic resonance imaging of the human temporal bone. ORL J Otorhinolaryngol Relat Spec 1991; 53:357-61.

11) Koizuka I, Seo Y, Murakami M, Seo R, Kato I. Micromagnetic resonance imaging of the inner ear in the guinea pig. NMR Biomed 1997;10:31-4. 